\title{
The Relationship between Religiosity and Emotion Regulation among Christian High School Students in Bangalore
}

\author{
Deepika Rachel R and Shambhavi Gundanna
}

\begin{abstract}
The study aimed to examine the relationship between Religiosity and Emotion Regulation among Christian High School Students in Bangalore. The study involved 120 participants, residing in India, studying in Christian Schools and belonging to the age group of 13 to 16 years. The study employed a quantitative research design and the sample was chosen using random sampling technique. Religiosity was determined using The Centrality of Religiosity Scale while Emotion Regulation was determined using the Emotion Regulation Questionnaire. Results of the study were analyzed using Independent Sample t-test and Pearson Product Moment Correlation. The results of the study were that there is significant relationship between Religiosity and Emotion Regulation among Christian High School Students. There is a significant difference in Religiosity among Christian boys and girls. There is no significant difference in Emotion Regulation among Christian boys and girls. It was concluded that there was a significant relationship between Religiosity and Emotion Regulation among Christian High School Students.
\end{abstract}

Keywords - Religiosity, Emotion Regulation, Adolescents, Christian Students.

\section{INTRODUCTION}

Religiosity plays a major part in the life of an individual. Previous studies have shown that the practice of religion has a significant effect on happiness and overall sense of personal well-being and that there had been always positive associations between religion and mental well-being which eventually enhances general psychological functioning . There are various types of religious practices, such as prayer, yoga and meditation, which have a significant effect on psychological well-being and over all functioning of the body [1]. To be religious is to be "excessively or sentimentally religious" or to practice one's religion in a meddlesome way. Thus, religiosity is characterized by excessive involvement in religious activities. Religiosity usually entails extreme zeal outside of and beyond the norms of one's faith. It is more than affection for religion; it is affectation in religion. Religiosity usually reflects one's individual beliefs more than those of the religious organization itself. Another term for religiosity, though less common, is religiousness, "the state of being superficially religious" [2]. The goal of religious education is

Deepika Rachel R, Jain University, India

Shambhavi Gundanna, Jain University, India to produce religious persons who are capable of acting in Christian (pro social) ways in everyday life (Groome, 1998). Emotion regulation or regulation of emotion is the ability to respond to the ongoing demands of experience with the range of emotions in a manner that is socially tolerable and sufficiently flexible to permit spontaneous reactions as well as the ability to delay spontaneous reactions as needed. Every day, people are continually exposed to a wide variety of potentially arousing stimuli. Inappropriate, extreme or unchecked emotional reactions to such stimuli could impede functional fit within society; therefore, people must engage in some form of emotion regulation almost all of the time [3]. There are two emotion regulation strategies: reappraisal and suppression [4].

A study found that those who considered themselves as religious were healthier, enjoying Subjective Well- Being, and obtained lower scores on neuroticism (Ahmed M. AbdelKhalek 2009) [5]. Another study suggested that socialization through religious participation in a congregational setting may also promote pro-social and adaptive qualities, elevating mood and decreasing levels of distress. It was found girls were more religious than boys. Religiousness is positively associated with pro-social values and behavior, and negatively related to suicide ideation and attempts, substance abuse, premature sexual involvement, and delinquency (Michael J. Donahue, Peter L. Benson 1995) [6]. A research has suggested that through self-regulation, religious individuals may be able to strive for high standards and simultaneously maintain high emotional well-being [7]. The results of the research suggest that some seemingly irrational aspects of religion may have important psychological benefits by promoting implicit selfregulation (Sander L. Koole et al. 2009)[8].

\section{METHODOLOGY}

The study attempted to understand the relationship between Religiosity and Emotion Regulation among Christian high School Students. Immense amount of research has gone into understanding the current variables and this chapter deals with the nature of the study, its objectives, the formulated hypotheses as well as describing the procedure along with the tools used for the current study in full. The aim of the study was to determine the relationship between religiosity and emotion regulation among school children in Bangalore. 
The objectives of the study were to understand the relationship between religiosity and emotion regulation of students, to compare religiosity and emotion regulation of boys and girls.

Null hypotheses were set because there has been a lack of studies that demonstrate a relationship between both the variables within a study, especially in the Indian setting. So there is not much to base the direction of the hypotheses.

1. There is no significant difference in Religiosity between boys and girls.

2. There is no significant relationship between Religiosity and Emotion Regulation among Christian High School Students.

3. There is no significant difference in Emotion Regulation between boys and girls.

The study is Correlational in nature, attempting to check for a relationship between Religiosity and Emotion Regulation among Christian High School Students.

The sample of the study consisted of 120 Christian High School Students in Bangalore, India, within the age group of 13 to 16 years. The sampling method used was Random Sampling. The Christian Schools that were a part of this study were Carmel Convent High School, Holy Spirit School and St.Ann's School from Bangalore. The questionnaires were manually administered to all the participants. A brief description of the study was presented to all the students along with the consent forms. The estimated time consumed to complete both the questionnaires was around 20 minutes. The Centrality of Religiosity questionnaire was administered first. It has a total of 15 questions with 5 points Likert-Scale. The Emotion Regulation Questionnaire was administered second. It has a total of 10 statements with 7 points Likert-Scale. The tools used for assessment were Consent Form, SocioDemographic Form, The Centrality of Religiosity Scale and Emotion Regulation Questionnaire. The Centrality of Religiosity Scale was developed by Stefan Huber and Odilo W.Huber in 2012.It is a method of determination of the level of Religiosity. It has a total of 15 questions. In this tool, most common are single item scales asking for a self report on the subjective importance of religion or the salience of religious identity. These allow the most economical assessment of the general intensity of religiosity. Construct Validity: amounts to 0.83 in a students' sample and 0.73 in the international Religion Monitor .Emotion Regulation Questionnaire was developed by Gross and John in 2003.The tool is a 10-item scale designed to measure respondents' tendency to regulate their emotions in two ways: (1) Cognitive Reappraisal and (2) Expressive Suppression. Respondents answer each item on a 7-point Likert-type scale ranging from 1 (strongly disagree) to 7 (strongly agree)[10]. The measure has demonstrated adequate to good internal consistency and temporal stability [11] (Gross and John, 2003; Sala et al., 2012; Batistoni et al., 2013), as well as sound convergent and discriminant validity (Gross and John, 2003; Balzarotti et al., 2010; Cabello et al., 2012).

\section{RESULTS AND DISCUSSION}

TABLE I (A)

SHOWING T-TEST SCORES OF RELIGIOSITY OF BOYS AND GIRLS

\begin{tabular}{|c|c|c|c|c|}
\hline & Mean & S.D & $\begin{array}{l}\text { Std. } \\
\text { Error } \\
\text { Mean }\end{array}$ & $\mathrm{T}$ \\
\hline Score & 65.95 & 6.45 & 0.833 & $2.886^{* *}$ \\
\hline & 62.73 & 5.73 & 0.739 & 2.886 \\
\hline
\end{tabular}

**-significant at 0.01 level, *- significant at 0.05 level

To analyze if Religiosity differs among boys and girls, an independent samples t-test was done. Table I (a) shows the score of the sample in independent sample t-test. The mean score of girls in Religiosity is 65.95, S.D is 6.45 and standard error mean is 0.833 . The mean score of boys in Religiosity is 62.73, S.D is 5.73 and standard error mean is 0.739 . The scores are significant at 0.01 levels which mean that there is significant difference between boys and girls. The results suggest that girls are more religious than boys. This finding is similar to the findings of the study by Michael J. Donahue, Peter L. Benson (1995) on Religion and the Well-Being of Adolescents. It was found that 'girls were more religious than boys'. One reason as to why women are more religious than men throughout Christian history maybe because women are tended to spend more time than males in raising and nurturing children and also therefore participating more in church activities because women then had flexible day schedules than men therefore spending more time in the church especially during the week days. Hypothesis 1 was rejected on the basis that there is significant difference in Religiosity between boys and girls.

TABLE I (B)

SHOWING T-TEST SCORES OF EMOTION REGULATION OF BOYS AND GIRLS

\begin{tabular}{|c|c|c|c|c|}
\hline & Mean & S.D & $\begin{array}{c}\text { Std. } \\
\text { Error } \\
\text { Mean }\end{array}$ & T \\
\hline Score & 47.05 & 7.911 & 1.021 & $0.381 * *$ \\
\hline & 46.46 & 8.84 & 2.141 & 0.381 \\
\hline
\end{tabular}

**-not significant at 0.01 level, *-not significant at 0.05 level

To analyze if Emotion Regulation differs between boys and girls, an independent samples t-test was used. Table I (b) summarizes the result of independent sample $t$ test. The mean score of girls in Emotion Regulation is 47.05, S.D is 7.911 and standard error mean is 1.021. The mean score of boys in Emotion Regulation is 46.46, S.D is 8.84 and standard error mean is 2.141. The scores are not significant at 0.01 levels which mean that there is no significant difference between boys and girls. The results suggest that there is no difference between boys and girls in Emotion Regulation. One main reason for there being no difference could be that the families of children are encouraging them to be more open and regulate their emotions better, especially in front of others. Children wouldn't want to express their sadness or cry in front of their peer group. Both boys and girls might have been raised in the 
same way in regard to controlling and expressing their emotions. Hypothesis 2 was accepted on the basis that there is no difference in Emotion Regulation between adolescent boys and girls.

TABLE I (C)

SHOWING THE RELATION BETWEEN VARIABLES OF RELIGIOSITY AND EMOTION REGULATION

\begin{tabular}{|c|c|c|}
\hline & Religiosity & $\begin{array}{c}\text { Emotion } \\
\text { Regulation }\end{array}$ \\
\hline Religiosity & & $.359^{* *}$ \\
\cline { 2 - 3 } & .000 \\
\hline $\begin{array}{c}\text { Emotion } \\
\text { Regulation }\end{array}$ & $.359^{* *}$ & 1 \\
\hline
\end{tabular}

*Correlation is significant at 0.05 level. **Correlation is significant at the 0.01 level

Table I (c) represents the results obtained on running a Product Moment Correlation, to understand the relationship between Religiosity and Emotion Regulation.A Pearson's product-moment correlation coefficient was computed to assess the relationship between Emotion Regulation and Religiosity. This deals with the testing of hypothesis 3 .

The Correlational value obtained for Religiosity is 0.359 $(\mathrm{p}=0.01)$. There is a positive significant relationship between Emotion regulation and religiosity as the value obtained is significant at the 0.01 level. This means that being religious can increase emotion regulation of the individual. There can be various reasons as to why these two variables correlate. Being religious can help individuals to reappraise Religious texts (The Holy Bible) says that suffering is good and even in bad situations one must stay positive._2 Timothy 3:12 New International Version (NIV) quotes "In fact, everyone who wants to live a godly life in Christ Jesus will be persecuted", James 1:19 New International Version (NIV) quotes "My dear brothers and sisters, take note of this: Everyone should be quick to listen, slow to speak and slow to become angry". These are some of the religious texts from the Holy Bible that suggest that people should be positive even if in a negative situation. Individuals who are religious and follow such religious texts might reappraise more and experience more positive emotions and less negative emotions and also express more positive and less negative emotions. Being religious can help individuals in Suppression (changing the way one responds behaviorally to an emotion-eliciting event). Again referencing texts from The Holy Bible, Matthew 5:38 quotes "You have heard that it was said, 'An eye for an eye and a tooth for a tooth.' But I say to you, Do not resist the one who is evil. But if anyone slaps you on the right cheek, turn to him the other also". Romans 12:21 New International Version (NIV) quotes "Do not be overcome by evil, but overcome evil with good". Proverbs 15 New International Version (NIV) quotes "A gentle answer turns away wrath, but a harsh word stirs up anger". The above verses suggest that the person must not respond negatively to an emotion- eliciting event or person but rather change the way one responds. One who follows these texts might apply it in real life and suppress his emotions when there are negative stimulations around him.
Hypothesis 3 is rejected on the basis that there is significant relationship between Religiosity and Emotion Regulation.

\section{CONCLUSION}

The study has found that there is a relationship between Emotion regulation and Religiosity among Christian Adolescents. Some of the implications of this study are that the study can be used to understand the various other emotional benefits of being religious and provides scope for further research on the areas of religiosity and how it affects a person's overall well being. This study can be used to understand and to motivate schools and students to involve in religious practices. The same study can be done on different population and the result can be compared as many studies suggest that the level of religiosity of a person changes according to age. New studies can be done to understand the reason behind why school students are religious.

\section{ACKNOWLEDGMENT}

Deepika Rachel $\mathrm{R}$ thanks Mrs. Shambhavi Gundanna, Assistant Professor, Jain University, for her constant guidance and support for this study. Special thanks to the principals of Carmel Convent High School, Holy Spirit School and St.Ann's School, Bangalore, for permitting data collection from their Institutes.

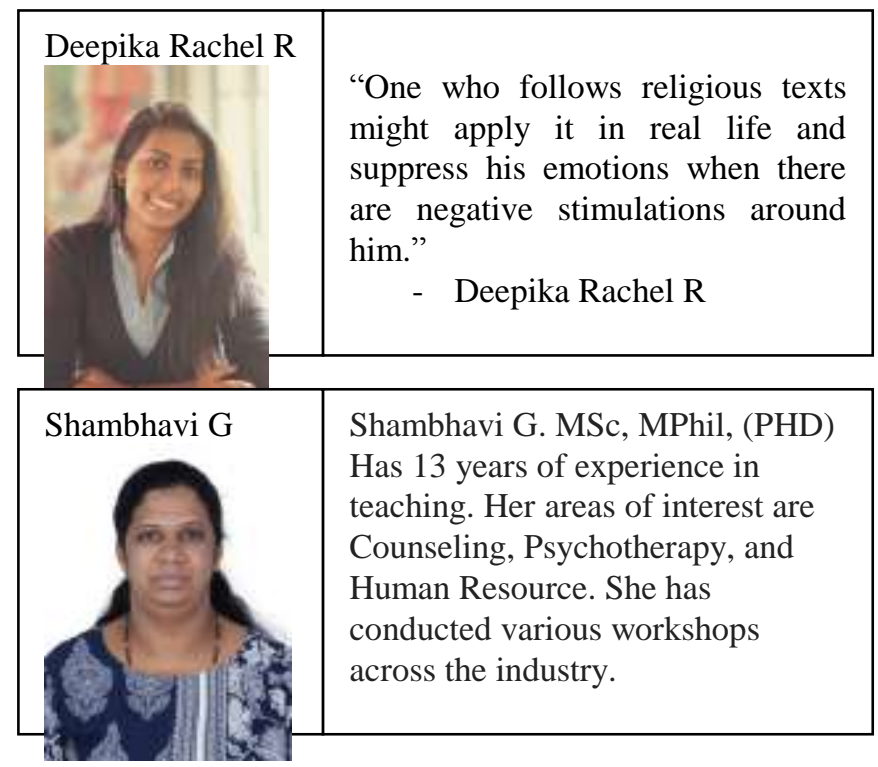

\section{REFERENCES}

[1] Medind.nic.in. (2008). Religious Belief and Its Relation to Psychological Well-being. [online] Available at: http://medind.nic.in/jak/t08/i2/jakt08i2p345.pdf [Accessed 19 Jul. 2018].

[2] What is religiosity? (2018). Retrieved from https://www.gotquestions.org/religiosity.html

[3] Emotional self-regulation. (2018). Retrieved from https://en.wikipedia.org/wiki/Emotional_self-regulation

[4] Strauss, G., Ossenfort, K., \& Whearty, K. (2016). Reappraisal and Distraction Emotion Regulation Strategies Are Associated with Distinct Patterns of Visual Attention and Differing Levels of Cognitive Demand. 
[5] Abdel-Khalek, A. (2012). Subjective well-being and religiosity: a crosssectional study with adolescents, young and middle-age adults. Mental Health, Religion \& Culture, 15(1), 39-52. doi: $10.1080 / 13674676.2010 .551324$

[6] Donahue, M., \& Benson, P. (1995). Religion and the Well-Being of Adolescents. Journal Of Social Issues, 51(2), 145-160. doi: 10.1111/j.1540-4560.1995.tb01328.x

[7] Koole, S., McCullough, M., Kuhl, J., \& Roelofsma, P. (2009). Why Religion's Burdens Are Light: From Religiosity to Implicit SelfRegulation. Personality And Social Psychology Review, 14(1), 95-107. doi: $10.1177 / 1088868309351109$

[8] Creativity, S. (2018). Using spirituality as a tool to restore implicit selfregulation and encourage holistic growth. Retrieved from http://www.shaman-australis.com/forum/index.php?/topic/45413-usingspirituality-as-a-tool-to-restore-implicit-self-regulation-and-encourageholistic-growth/

[9] Gross, J.J., \& John, O.P. (2003). Individual differences in two emotion regulation processes: Implications for affect, relationships, and wellbeing. Journal of Personality and Social Psychology, 85, 348-362 https://doi.org/10.1037/0022-3514.85.2.348

[10] Ioannidis, C., \& Siegling, A. (2015). Criterion and incremental validity of the emotion regulation questionnaire. Frontiers In Psychology, 6. doi: 10.3389/fpsyg.2015.00247

https://doi.org/10.3389/fpsyg.2015.00247 